

\section{Evaluation of Relationship between Oil Revenues and Government Budget in Iraq: 2006-2016 Period}

\author{
Mehmet Dă̆ \\ Semih Serkant Aktuğ \\ Zavar Salah Ali Alı
}

\section{Introduction}

Oil production is frequently reflected as a political commodity. So, since its essential significance as a crucial source of energy, governments are concerned for its continued availability and pursue to minimize import reliance. Hence, energy and in particular oil is one of the essential elements and pillars of societies and nations. All economic sectors need energy, such as transportation, electricity, household appliances, and so on. Thus, the oil industry has become one of the essential modern industries of the global industrial economy (Haddad, 1989).

Devolde (2006) mentioned that, oil is the main engine of global economy. It is one of the most important criteria that have a global influence, both economically and politically and it is one of the signs that focus on human civilization, and among all other sources of energy. Oil is one of the most strategic commodities in the world. Today, oil is considered as the lifeblood of industry, in addition to its high degree of safety, unlike other sources.

According to Basri and Al-Sebahi (2013), Iraq is estimated to be one of the fastest developing countries in the region and the country could experience further growth, if oil and gas law as well as governing reform permits. So, recent years have undoubtedly revealed that Iraq's socio-economic problems can be attributed to the ineffective use of oil revenues and too weak institutions, which have become a constraint to delivering even essential services. However, according to the Arab Energy Conference AEC (2014), oil is known in Iraq since its early appearance on the surface of the earth, where old Iraqis used it to build and paint boats, as well as burn it in the eternal fire in Kirkuk. The Babylonians launched the name of oil on the Kair, which was found in the form of a solid block on the sides of the Euphrates River and knew how to use it in the construction and manufacture of water transport as well as paving roads. Oil was also used by the Assyrians in various industries.

Thus, Iraq was subjected to the struggle of foreign countries to obtain the privileges of prospecting in its territory. The states tried to obtain oil concessions from the Ottoman Empire when Iraq was part of the Empire. This conflict still continues following the
American companies entering Iraq (Battat, 2010). Following this concession, the granting of another concession to Mosul Petroleum Company and finally the granting of the Basra Petroleum Company's concession and granting Iraq the concession of using oil in the Khanaqin area of the Khanaqin Oil Company are other important issues. The government ended its franchise in 1958, because the company did not implement its commitments and took the process of producing oil directly from Khanaqin fields (Alnasrawi, 1994). As Battat (2010) mentioned, the oil production began in Iraq for the first time in Kirkuk on October 15, 1925 when the British government (the direct ruler of Iraq) granted a concession to Turkish Petroleum Corporation (TPC). The oil was extracted in Baba Ghargar and is now one of three domes in the Kirkuk fields.

The study found that, Iraq's oil production curve in recent years has remarkably specified the positions, even if not mainly at the levels estimated earlier. Iraq has developed to be the world's fourth-largest oil exporter. Moreover, it is the second major producer in OPEC organization, with a production above 4.1 million bpd for the first time in 2015. The amount was roughly 4.5 million bpd in 2016 for Northern Iraq. Also in 2017, the country also proved a new record for annual exports. However, production levels in 2006 were just 2 million bpd, demonstrating a more than doubling of production during a ten-year period (Iraq Oil Report, 2014). While challenges continue to achieve the aims of increased oil production, there is considerable opportunity for Iraq's resources to produce revenue and pay for broad-based economic development, if managed appropriately.

The oil prices have significant impacts on Iraq's revenues and all its economic sectors. Through 2006 to 2008, oil prices in international markets sharply increased from $\$ 55.60$ to $\$ 91.50$ in 2008 , just before losing its value by nearly $40 \%$ in 2009 . Once again, oil price in the global oil markets suddenly increased from $\$ 74.20$ in 2010 to $\$ 106.70$ in 2012 . This was due to increases in demands of oil markets, particularly more demands coming through China and India. However, just after the oil price reached the highest level in ten years, it started to decline from $\$ 102.90$ in 2013 to $\$ 34.50$ in 2016 , which lost $68 \%$ of its value.

Iraq's energy sectors will remain to be an essential portion of the Iraqi economy for many years to come. Oil revenue provides the bulk of Iraqi national budget, as well as the budget in the KRI, that provides a vital source of revenue and funds for recovery and development. So, the decline in oil prices will lead to significant shortages and create significant problems for Iraqi rebuilding and sustainable economic development.

\section{The Oil Production of Iraq}

The oil sector is the heart of the Iraqi economy, where $95 \%$ of the revenues of the state come from oil production. Thus oil regarding discovery and the level of reserves, production, oil prices, and exports are also essential for the Iraqi economy (Basri \& Al-Sebahi, 2013). The oil industry is the basis on which the Iraqi economy depends. But the destruction that has hit the 
sector in recent years after 2003 has exposed this sector to looting and sabotage, which targeted the infrastructure of production and export mainly as well as the lack of investment (Alnasrawi, 1994).

Iraq is among the countries with a rich and varied resource base. It is the third largest known global reserve after Saudi Arabia and Iran, with abundant water resources. There is also a sizeable national workforce of more than 7 million people of the Arab oil countries. These resources can, within a decade, bring Iraq back to its former status as a middle-income country. The average poverty rate in Iraq ranges between $8-10 \%$. Between $12-15 \%$ is prone to decline to a similar level regarding the proportion of Iraqi population (Portman, 2005). However, Iraq currently ranks as one of the poorest countries in the world despite its unlimited resources. This is due to structural imbalances in its agriculture, industry, and even oil-producing institutions, which are due to at least war-production levels. Iraq is a country that depends on other countries at a high rate. It also gives considerable attention to the public sector by ignoring the private sector. That is still observed despite the increasing calls of international institutions to pay attention to the private sector (Hammadi, 2010).

The Iraqi oil fields are divided into four areas: Southern fields, central fields, northern fields and the fields of Northern Iraq. The Rumaila region in the southern field has the highest level of production at 1430 million barrels per day. The West Qurna region is the second largest oil region in Iraq located in the southern fields with a daily production level of 550 thousand barrels per day, which consists of about one-sixth of the total production in the southern fields (Oil \& Gas Journal, 2016).

According to Hammadi (2010), economists also classify Iraq's oil fields as the World's unique one regarding the low cost of production because crude is close to the surface and it is without geological obstacles. One of the encouraging characteristics of investment in this sector is related with existing fields. There is a small amount of production of Iraqi oil compared to the stock. The wells produced in Iraq range from 1500 to 1700 wells, while the wells are expected to be a subject of search for at least 100 thousand wells.

In the same regard, Rubaie (2006) argued that the majority of Iraq's oil reserves are concentrated in large fields. About $40 \%$ of the total fixed reserves concentrated are in 15 developed fields, where $69 \%$ of the reserves concentrated are in the first category, which contain more than 5000 million barrels. $24 \%$ of the reserves concentrated are in the second category, which range between 1000-5000 million barrels. 58 non-developed fields contain $60 \%$ of Iraq's total fixed reserves.

However, according to Manhal (2006), the Iraqi economy in the current stage of the economies is onesided. This is still observed despite Iraq's vast agricultural and industrial potential. However, the control of oil revenues on GDP is what made it unilateral.

\section{Iraq's Oil Data, Oil Production and Budget Revenue Statistics}

Iraq is a founding member of OPEC, thus the country always joined its meetings, even after 1991. However, there are many unresolved concerns in an attempt to reliably analyze a future relationship between Iraq and OPEC, although many factors refer to Iraq's remaining membership in OPEC. In addition to OPEC's participation as a typical situation, Iraq's neighbors are also geographically involved. Thus, Iraq's share in the global oil market will grow as exports expand, and OPEC provides a safety cushion for oil prices.

Despite significant improvements in increasing oil production and smaller but equally meaningful advances in gas development, difficulties for Iraq to reach its production potential still continue. In addition to confiscating obstacles to improved production and export progress, maybe the major challenge for Iraq is sustainably managing the resulting resource revenue in a way that serves the country's long-term growth benefits and improves the living conditions for all Iraqis. Sustainable management of resource revenue, along with making the foundation for a more diversified economy, is critically important both for Iraq and the KRI (Scholl, 2018).

As shown in Figure 1, Iraq's daily oil production always increased through the period of 2006-2016.

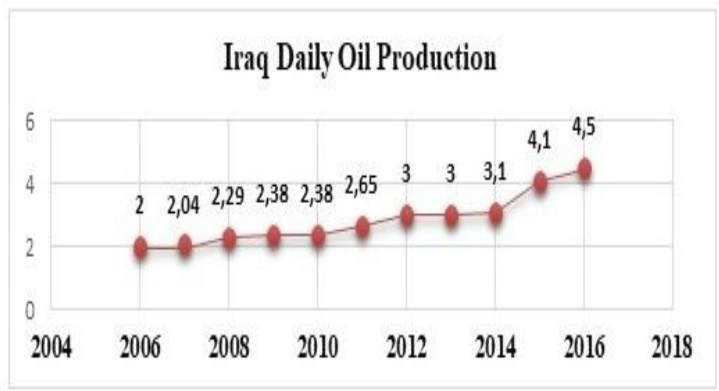

Figure 1. Iraq Daily Oil Production

Source: Iraq's Ministry of Oil (2016).

Figure 2 shows Iraq's total petroleum and consumption. The Gulf War in 1990-91 and Iraq War beginning in 2003 dramatically impacted Iraq's oil production capacity. Through the Gulf War, Iraq's daily production decreased from over 2.0 million bpd in 1990 to around 400,000 bpd. The Iraq War beginning in 2003 also declined the country's levels of production. On the positive side, starting from 2005, the oil production levels in Iraq gradually increased. 


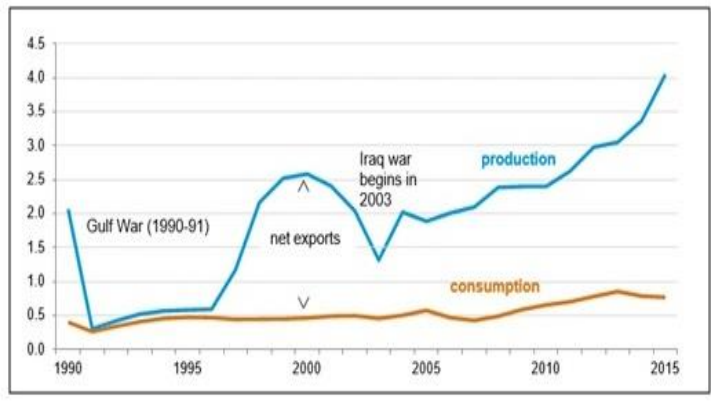

Figure 2. Iraq's Total Petroleum and Consumption

Source: EIA, (2016).

The first Gulf War and subsequent sanctions devastated the already exhausted economy. The bombing campaign of 1990-1991 has severely damaged or destroyed many of the oil infrastructure, transport, energy, and industrial infrastructure. The government initially directed its efforts to reform the oil and telecommunications infrastructure as well as the state security apparatus. A rationing program was introduced to disseminate available food and consumables. However, the government's policy had a fundamental reaction, since the sanctions regime (and system priorities) had left little to restore and develop the economy. Due to Iraq's dependence on international trade in oil for the functioning of its economy, the sanctions regime had an immediate damaging effect. So, the oil for food program improved this situation. However, the shortages, hyperinflation and the absence of international trade characterized the Iraqi economy in the 1990s (EIA, 2015).

Oil production in Iraq did not stabilize at a certain level. It witnessed a significant decline, especially in the 1990s, due to the embargo imposed on the country. Of course, the economic blockade is an exceptional factor. Oil production in all countries of the world is affected by other factors. The aspects influencing oil production is affected by three factors: Exploring the process of new oil fields, raising the level of exploitation of working fields, and prices-sources of supply of energy sources.

Table 1 shows the budget and oil production statistics of Iraq for the 2014-2016 period. Figure 3 illustrates the budget and oil production statistics of Iraq. Both Table 1 and Figure 3 indicate that, Iraq depends on oil revenues more than any other Middle Eastern country. As previously mentioned, Iraq's oil production amounts to two-thirds of its GDP. According to Joseph (2016), nearly $95 \%$ of central government revenues and $99 \%$ of total export revenues of Iraq arise from oil. In 2014, Iraq's total revenues had accounted to 104 billion US dollars, were 99 billion were gained from oil exports. However, the entire country's expenditures were 119 billion US dollars, which led to a $14 \%$ budget deficit. Declining oil prices led to the increase in budget deficit in 2015 , by $26 \%$, due to a decrease in oil price by $48.9 \%$. In 2016, the oil price (per barrel) declined to $34.50 \%$. But in that period, Iraq increased its oil exports to $4.5 \mathrm{mbpd}$, thus the budget deficit declined to $17 \%$. So, this result confirms that the critical element for Iraq's economy is oil and $97 \%$ of the government revenues are composed of oil exports.

Table 1: Budget and Oil Production Statistics of Iraq for the 2014-2016 Period

\begin{tabular}{|l|r|r|r|}
\hline & $\mathbf{2 0 1 4}$ & $\mathbf{2 0 1 5}$ & $\mathbf{2 0 1 6}$ \\
\hline Total Revenues & 104 & 63 & 66 \\
\hline From Oil Exports & 99 & 58 & 58 \\
\hline $\begin{array}{l}\text { Oil Price (per } \\
\text { barrel) }\end{array}$ & $\$ 97.00$ & $\$ 47.50$ & $\$ 34.50$ \\
\hline Oil Exports & $3.1 \mathrm{mbpd}$ & $4.1 \mathrm{mbpd}$ & $4.5 \mathrm{mbpd}$ \\
\hline $\begin{array}{l}\text { Total } \\
\text { Expenditures }\end{array}$ & 119 & 89 & 83 \\
\hline $\begin{array}{l}\text { Current } \\
\text { Expenditures }\end{array}$ & 70 & 58 & 66 \\
\hline $\begin{array}{l}\text { Budget } \\
\text { Surplus/Deficit }\end{array}$ & -14 & -26 & -17 \\
\hline
\end{tabular}

Source: Iraq’s Ministry of Oil (2016).

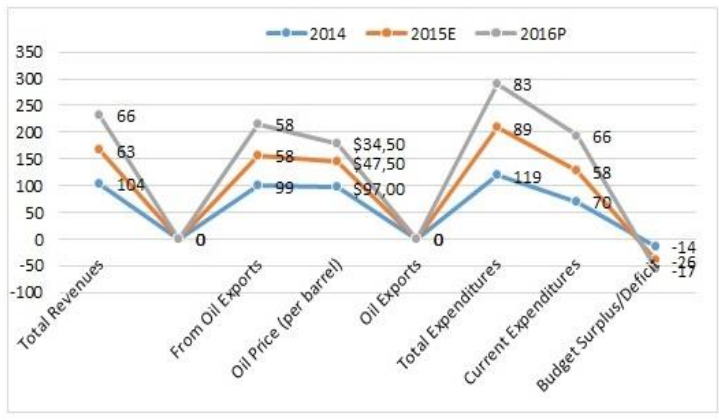

Figure 3. Budget and Oil Production Statistics of Iraq for the 2014-2016 Period

Source: Iraq's Ministry of Oil, (2016).

According to IMF, (2016) the oil price decline was caused by a substantial decrease in budget revenue, pushing the fiscal deficit to an unmaintainable level. Thus, the Iraqi authorities responded to the crisis with a mix of required fiscal adjustment and financing, sustaining their commitment to the exchange rate peg. The exchange rate peg system offers a main nominal anchor in a highly uncertain environment with policy capability destabilized by the war against ISIS.

Also, the Iraqi budget originates from oil revenues rather than taxation. This is a situation, which uses the income as a key "consensus builder," converting it into mostly unproductive public expenditure. Moreover, the negative impact of the energy sector's significance over other national production sectors is evident.

Future production prospects in Iraq contrast commonly. While most experts acknowledge the existence of proven reserves to meet the official target, unlike many regions of the world, geological hazards are virtually non-existent in Iraq. There is a general view that these figures are intended for public consumption. So, this view is realized in official figures as part of an intentional scheme to justify the re-entry of international oil companies into Iraq after nearly four decades of nationalization in the face of Iraqi people. However, this 
sector will be subject to continuing obstacles such as security, politics and infrastructure. Skeptics point to the fact that, within seven years Iraq would not reach pre-war levels of crude oil.

Iraqi government officials have interpreted spending decisions as a reaction to long-term trends in inadequate investment and insufficient payments from public salaries in Iraq as a result of war, isolation and civil war. In 2009, the budget shrank due to the collapse of the markets, but not as much as the decline in revenues in the world markets, which suffered a substantial decline and showed a massive fiscal deficit.

In this sense, Iraq has fallen victim to one of the traditional phenomena in the oil-producing countries, namely the growing reliance on oil revenues associated with a highly volatile income situation. The proposal to distribute partial oil revenues is mainly in line with planning economic situation of the government of Iraq and the international financial institutions. It is assumed that, public spending will rise moderately, just over $2 \%$ annually, in line with Iraq's annual population growth over the past few years, allowing public service and public investment to continue at current levels. It also assumed conservatively that, revenues of the government from the non-oil good and services will rise by about one trillion dinars ( $\$ 850$ million) per year, lower than the levels achieved in recent years.

Iraqi economy suffers from a severe shortage of capital, even when evaluated according to traditional concepts and works, before any consideration of questions of social inclusion. The World Bank issued a report indicating that state-owned banks own nearly twothirds of all state assets since the days of the former regime and that they represent the only financial institutions with branch networks throughout the country. The vast majority of these assets, in turn, belong to the state.

Therefore, new governments in both Baghdad and Erbil must recognize that ambiguity at this critical moment for oil markets, and as oil or gas development struggles to gain a position, that could negatively affect Iraq's standing as a low-cost producer with high potential. Undertaking this issue should be a priority as part of the governing command.

\section{Conclusion}

The primary purpose of this study was to examine the relationship between oil production and budget revenues in Iraq during 2006-2016. Firstly, it should be noted that, although challenges to increasing oil production in Iraq broadly remain, the country has made incredible progress over the last decade.

Iraq's economy is substantially reliant on oil revenues. So, in 2014, crude oil export revenue amounted to $93 \%$ of Iraq's overall public budget. According to the IMF (2015), Iraq (excluding Northern Iraq) received marginally more than $\$ 49$ billion dollars in crude oil export revenue in 2015 . That is $\$ 35$ billion less than in 2014, despite a substantial increase in export volumes, due to a sharply decline in oil prices from $\$ 97$ in 2014 to $\$ 47$ in 2015 .

The study found that, Iraq's oil production curve in the recent years has remarkably specified the positions, even if not mainly at the levels estimated earlier. Iraq has developed to be the world's fourthlargest oil exporter. Moreover, it is the second major producer in OPEC organization, with a production above 4.1 million bpd for the first time in 2015. The country's energy sectors will remain as an essential portion of the Iraqi economy for many years to come. Hence, oil revenue provides the bulk of the Iraqi national budget. That provides a vital source of revenue and funds for recovery and development. So, the decline in oil prices will lead to significant shortages and create significant problems for Iraqi rebuilding and sustainable economic development.

According to IMF (2016), the oil price decline was caused by a substantial decrease in budget revenue, pushing the fiscal deficit to an unmaintainable level. Thus, the Iraqi authorities responded to the crisis with a mix of required fiscal adjustment and financing.

On the other hand, regarding the events of fall 2017, these events illustrate the difficulties in continued reliance on budget transfers in Baghdad or oil exports facilitated by a neighbor country that sees the energy in geopolitical terms. The Northern Iraq should also focus on diversification, which can lay the groundwork for a more sustainable and politically-insulated economy over the long term. The development of a diversified economy that is not entirely dependent on oil revenues is also a must. Besides, one might argue that, Iraqi government shall develop alternative economic resources to oil revenues, which can help the stabilization of the national economy.

\section{References}

AEC. (2014). Iraq Republic Paper. The 10th Arab Energy Conference, Abu Dhabi, United Arab Emirates, 1-34.

Alnasrawi, A. (1994). The Economy of Iraq, Oil, Wars, Destruction of Development and Prospects, 1950-2010, London: Greenwood Press. Westport, Connecticut.

Battat, M. S. (2010). The Economic Effects of the Implementation of the Oil and Gas Law in Iraq. Al-Ghari Journal of Economic and Administrative Sciences, 3(17), 56-89.

Devolde, H. (2006). Oil and Gas Production, Handbook, An Introduction to Oil and Gas Production. 
EIA. (2015). Country Analysis Brief: Iraq. Washington D.C.: U.S. Energy Information Administration, U.S. Department of Energy. Retrieved 7 17, 2018 (July 17, 2018), from https://www.eia.gov/beta/international/analysis _includes/countries_long/Iraq/iraq.pdf.

Energy Information Administration (EIA). (2007). Official Energy Statistics from the U.S. Gov't, Iraq: Oil. Energy Information Administration. Retrieved 2 12, 2018, from www.eia.doe.gov/emeu/cabs/iraq/Oil.html.

Haddad, A. (1989). Petroleum Industry and Derivatives. Beirut, Lebanon: Institute for Arab Development.

Hammadi, I. O. (2010). Structural Imbalances in the Iraqi Economy: Diagnosis and Treatment (3rd Edition ed.). Iraq Center for Studies.

Hughes, M. P. (2011). Shaping and Re-Shaping Social Capital in Buyer-Supplier Relationship. J.Bus.Res., 64(2), 164-171.

IEA. (2011). Key World Energy Statistics. International Energy Agency.

IMF. (2015). IMF Country Report No. 15/235.

IMF. (2016). IMF Country Report No. 16/379. Washington, D.C.: International Monetary Fund Publication Services.

Iraq Oil Report. (2014). Despite March Exports Drop, Record Output for New Buoys. IOR.

Iraqi Ministry of Oil. (2016). Iraq Oil Report. Ministry of Oil. Retrieved 07 03, 2018 (July 3, 2018), from https://oil.gov.iq/index.php?name=Pages\&op= page $\&$ pid $=91$

Joseph, S. (2016). Iraq: Oil Prices and Economic Management. MEEA 15th International Conference, Doha.

Manhal, M. Y. (2006). Feasibility of Iraq's Accession to the World Trade Organization. Baghdad: University of Baghdad.

Oil \& Gas Journal. (2016). Worldwide Look at Reserves and Production. OGJ.

OPEC. (2006). Annual Statistical Bulletin 2005. Vienna: OPEC.

Portman, C. (2005). Reconstruction of Iraq: Economic Reform and Transition. World Bank.
Rubaie, K. F. (2006). Iraq's Oil Sector between Reality and Future Prospects. Baghdad: University of Baghdad.

Scholl, E. (2018). Shaping Iraq's Oil and Gas Future. Atlantic Council, Global Energy Center.

U.S. Energy Information Administration. EIA, (2016). Country Analysis Brief: Iraq. EIA. 